\section{Ethical Lingua}

Journal of Language Teaching and Literature

ISSN 2355-3448 (Print)

ISSN 2540-9190 (Online)

Volume 5, Number 2, August 2018 pp. $139-148$

\title{
Comprehending Narrative Text: The Effectiveness of \\ Cooperative Integrated Reading and Composition (CIRC)
}

\author{
Miftah Fariduddin ${ }^{1}$ \& Firman Parlindungan*2 \\ * firman@utu.ac.id
}

${ }^{1}$ Universitas Islam Malang, Indonesia

${ }^{2}$ Universitas Teuku Umar, Indonesia

\author{
Received : 23 November 2017; Accepted: 30 July 2018 \\ URL : : http://journal.uncp.ac.id/index.php/ethicallingua/article/view/716 \\ DOI : : https://doi.org/10.30605/ethicallingua.v5i2.716
}

\begin{abstract}
The aim of this study was to investigate whether there was significant difference on the students' reading comprehension of narrative text between those who were taught through Cooperative Integrated Reading and Composition (CIRC) method and those who were not. Forty-nine students were selected as the sample and quasi-experimental, non-randomized pre-test and post-test design were employed. The analysis of covariance showed that the students who were taught by using CIRC method statistically outperformed those who were not on their reading comprehension of narrative text, $(F(1,48)=13.56, p<.05)$. This result implies that CIRC is an effective method to teach reading comprehension, particularly on narrative text. Since this study only focused on narrative text, future researchers might be interested to seek the effect of CIRC on other text genres. Similar study though may be conducted with a randomized design of larger population.
\end{abstract}

Keywords: reading comprehension; CIRC; narrative text 


\section{Introduction}

In the vast literatures of reading research, comprehension has been becoming an essential component of reading both in its instruction and assessment (see e.g. Adams, 1990; National Reading Panel, 2000; Paris \& Stahl, 2005; Snow, Burns, \& Griffin, 1998). It solidifies the idea that the goal of reading is to understand information on texts, which involves interactive process between the reader, the text, and the context. Good readers engage deeply with those processes, monitor and evaluate what they read, and take advantage from what they read for their lives. Therefore, teaching students to become good readers is a difficult and challenging task that requires specific comprehension instructions (Block, Gambrell \& Pressley, 2002).

On the account of the above definition, it seemingly clear to assume that being able to read means having the capability to comprehend what is being read. According to Kintsch (2013), comprehension is understood as building a mental representation of a text. Levels of representation in reading range from perceptual, verbal, and semantic representations. In building semantic representation, readers need to identify propositions or idea units that allow them to represent the meaning of the sentences regardless of the syntactic structure. The meaning of a text is constructed by combining idea units or propositions in sentences and phrases, which is called microstructure of the text. In addition, meaning of a text is also related with higher order units, not just word meanings or propositions, which is called the macrostructure. It includes a process of identifying important themes or topics in a text.

Kintsch (2013) continued on saying that at the textbase level, a reader might understand the meaning of the text through the interrelationship taking place between the microstructure and the macrostructure of a text. However, it might be just happen at the surface level (i.e. explicit meaning). For a deeper understanding, a reader needs to construct a situation model or a mental model of what has been described within the text, which requires prior knowledge, readers' goal, and the world knowledge. All information processing takes place in the capacity of working memory. According to Cowan (2009), working memory is broadly defined as "short-term memory applied to cognitive tasks, as a multi-component system that holds and manipulates information in short-term memory, and as the use of attention to manage short-term memory" (p. 1). To this end, teaching reading comprehension might sound more abstract. What may classroom teachers do hence in their teaching practices?

Pearson and Fielding (1991) reviewed studies on text comprehension instruction and categorized text into narrative text and expository text. Instruction for narrative text emphasized the role of background knowledge and implied stories ideas, which in Kintsch's (2013) notion is at textbase level of processing 
by building mental model of the text. At this point, the main goal of teaching students to comprehend texts is an active involvement in reading. This can be done through activities, such as self-questioning, generative learning, and self-monitoring. Other factors like peer-interaction, student-teacher dialogue, and repeated reading are also beneficial to improve reading comprehension. Noted that comprehension instruction might be implemented in a variety of forms depending on task control (who decides learning task), task authenticity (how much real-life reading texts and task are), and teacher's role (how much teacher participation in the teaching and learning process).

Following the explanation above, Slavin (1988) has long proposed the notion of cooperative learning to teach reading, such as the cooperative integrated reading and composition (CIRC). This proposal is in line with what Kintsch's (2013) theory of reading comprehension. Three fundamental elements of CIRC include direct instruction in reading comprehension, treasures-hunt activities, and integrated language arts and writing. Treasures-hunt activities are the ones covering comprehension questions, predictions guidelines, new vocabulary to be learned, story retell, and story related writing. All activities though are conducted in small group interaction with series of steps, including teacher presentation, team practice, independent practice, peer-assessment, additional practice, and testing.

Durukan (2011) studied the effects of CIRC method and the traditional reading and writing pedagogical methods for primary school students. Based on the statistical analysis, it was revealed that there was a statistically significant difference between the reading and writing skills of the experimental and control groups in terms of academic achievement and retention. This difference was discovered favoring CIRC method. In a similar vein, Darmayanti (2014) studied the effect of CIRC method on students' reading comprehension of narrative text. 70 students were clustered as the sample students with 33 students in experimental group and 37 students as the control group. She found that there was significant difference between the students' score who were taught CIRC method and non-CIRC method.

Based on the explanation above, CIRC has been showed as an effective method to teaching reading comprehension of narrative text with students in different context. However, more studies are needed to confirm those findings. As such, we are interested to continue intellectual dialogues regarding the effectiveness of CIRC in teaching comprehension of narrative text, particularly in the Indonesian context. Teaching English narrative through CIRC will be expected to contribute to the development of teaching quality in the classroom to improve the student's reading comprehension and support the teacher in constructing suitable material based on the student's need, knowledge, and interest. 


\section{Theoretical Perspective}

Since CIRC entailed the importance of context and social interaction of learning, this study then is grounded in Vygotzkian's (1978) sociocultural perspective of language learning. Vygotskian's (1978) perspective of language learning emphasizes the central role of social interaction in learning. Learners actively construct meaning in interaction with others. Without denying learners as unique individuals, learning occurs in line with language development through social and cultural practices (as cited in Wood, 1998). For Vygotsky, language is not only a medium for learning, but also learning itself. Children use language in the interaction of cognitive and social processes with their peers by presenting their ideas and experiences verbally in social learning environments. Learning may also occur by the use of scaffolding language by teachers or adults who are more knowledgeable others in which children may not be able to solve the problem independently. Later, learners gradually internalize higher cognitive inputs that become thought. To this end, learning happens first in the intercognitive process where children share their social speech, and then they move to the intracognitive process where children have their private speech to problem solve (As cited in Kong \& Pearson, 2003). After that, children internalize higher cognitive inputs in which adult language is not merely appropriated by the child, but that the child take the language exchange and transform it into their inner speech. That is how thinking and language are developed in Vygotsky's notion (1978).

\section{Method}

In this study, we employed experimental research to measure which of between two techniques CIRC or conventional is more effective. The design was quasi-experimental non-randomized design to prove the hypothesis. This design was used because it was impossible to assign the subjects randomly to group, interrupt the schedule of the class, and reorganize the class for the research purpose. According to Ary, et al (1979), experimental design refers to the conceptual framework in which the experiment is conducted. It serves within two functions: (1) to establish the conditions for the comparisons required by the hypothesis of the experiment, and (2) to enable the experimenter through statistical analysis of the data to make a meaningful interpretation of the results.

\section{Population and Sample}

The populations in this study were the tenth-year students taking English subject at SMK An-Nur Sampang which consist of 49 students from two classes; first class was named X-1 and the second class was X-2. The sample was within a non-randomized design so that the researcher could directly divide the $X-1$ class as the control group and X-2 class as the experimental group. 


\section{Data Collection}

The instrument in this study was reading test, which include pre-test and post-test. The type of reading test was in the form of multiple-choice and composition. The multiple-choice tests consisted of 20 items and five options in every item, and students were asked to compose a simple narrative passage by 100 words based on students' perception about fairytale of folktale as the theme. The composition was used to measure the students' ability to compose a passage after they read a passage. The test items were developed based on the instructional objective in the materials and the level of reading comprehension. The type was chosen because it was appropriate with the material and the reading levels of the students as informed by the English teacher. The research instruments were administered for the pre-test and post-test for both experimental and control groups. Pre-test and post-test contained some items and passages of narrative texts about fable and fairytale.

\section{Intervention}

After pre-test was administered for both control and experimental group, the treatment for both experimental group and control group started. Each group had different teaching strategies. The experimental group was taught by using $\mathrm{CIRC}$ and the control group was taught by using conventional teaching strategy. The procedure of the two techniques involved three phases of teaching and learning activities: pre-reading, meanwhile reading, and post-reading activities. The table below displays the difference of the teaching procedure between two groups.

Table 1. The Intervention for Control and Experimental Group

\begin{tabular}{|c|c|}
\hline Experimental Group & Control Group \\
\hline $\begin{array}{l}\text { 1. Inform the students about the topic that } \\
\text { will be discussed, and the goal of learning. } \\
\text { 2. Direct the student with leading questions } \\
\text { related to the text. } \\
\text { 3. Asking the students to respond to the } \\
\text { information in the text. }\end{array}$ & $\begin{array}{l}\text { 1. Inform the students about the topic that } \\
\text { will be discussed, and the goal of } \\
\text { learning. } \\
\text { 2. Direct the students with leading } \\
\text { questions related to the text } \\
\text { 3. Explain the reading text to the students }\end{array}$ \\
\hline $\begin{array}{l}\text { 1. Divide the students into heterogeneous } \\
\text { groups of five. }\end{array}$ & $\begin{array}{l}\text { 1. Ask the students to read the passage out } \\
\text { loud. }\end{array}$ \\
\hline $\begin{array}{l}\text { 2. Ask the students to start working in groups } \\
\text { by reading together in which each student } \\
\text { in one group substitutes to read aloud in } \\
\text { different paragraphs. }\end{array}$ & $\begin{array}{l}\text { 2. Provide opportunities for students to ask } \\
\text { any difficult vocabularies. } \\
\text { 3. Ask the students to discuss the difficult } \\
\text { words and grammatical items. }\end{array}$ \\
\hline $\begin{array}{l}\text { 3. Ask the students to cooperatively read \& } \\
\text { find the main idea, explicit \& implicit } \\
\text { information, and several ones of the text. }\end{array}$ & $\begin{array}{l}\text { 4. Ask the students to translate the reading } \\
\text { passages. } \\
\text { 5. Discuss the text with the whole class. }\end{array}$ \\
\hline
\end{tabular}




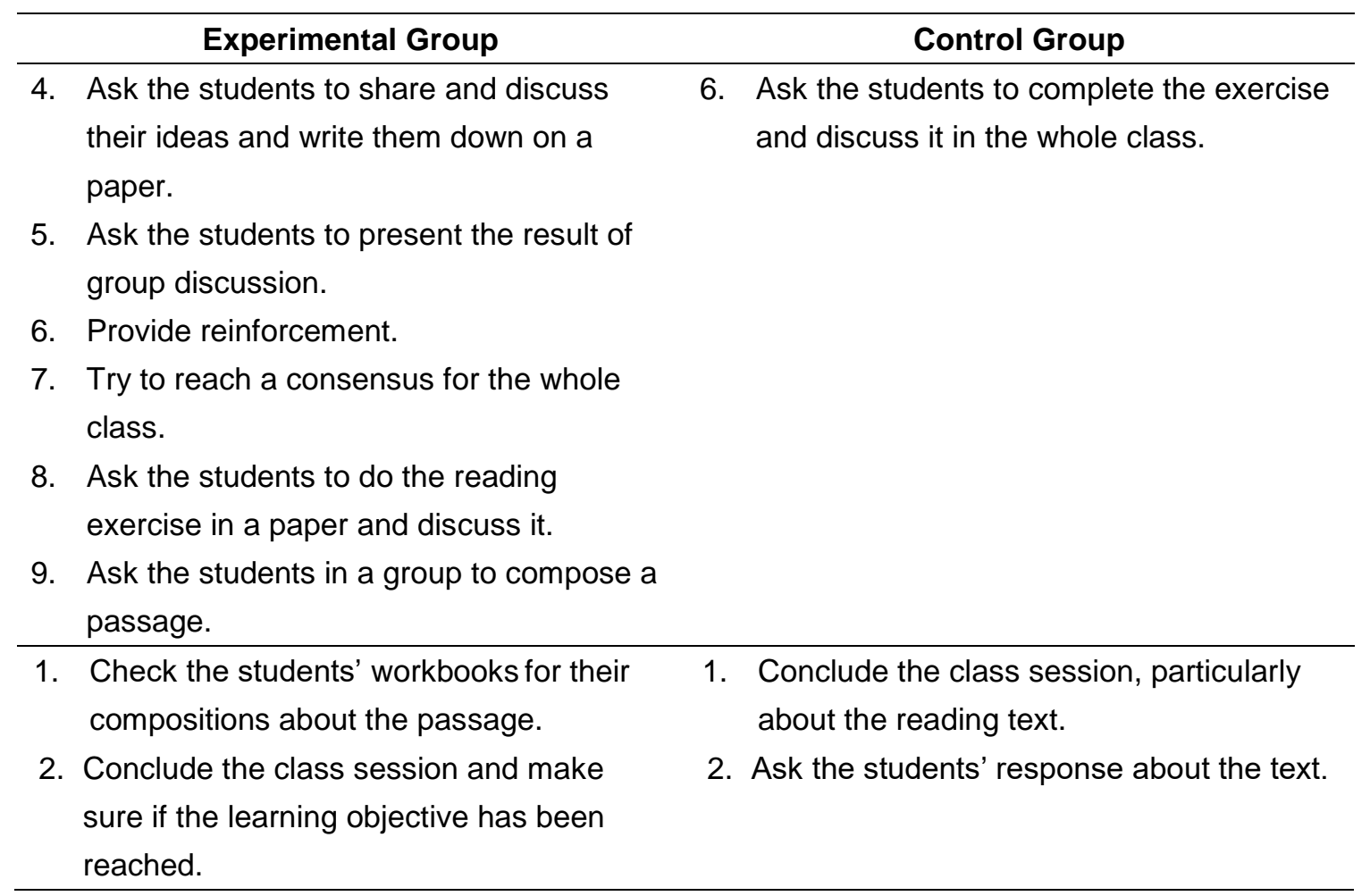

\section{Data Analysis}

Analysis of Covariance (ANCOVA) was employed for data analysis. ANCOVA is the combination between correlation and analysis of variance. In ANCOVA analysis, we can control the effect of variables besides independent ones. The idea is to test whether there are differences between groups on a dependent variable, or set of variables. The pre-test score was analyzed to determine whether the means and standard deviation of the two groups differ significantly. If the score for the two groups on the pre-test are not equivalent, then the analysis of covariance technique is used. Additionally, the post-test is applied to spot the effect of treatment, the score of post-test compared with the pre-test score and tested at 0.05 level of significance to determine the effect of the treatment. The variables examined in this experimental research were the independent and dependent ones. The independent variable was teaching narrative text using CIRC, and the dependent variable was student's reading comprehension.

\section{Results \& Discussion}

The descriptive statistics of the pre-test for both control and experimental group showed that the mean score of experimental group (in this case group which is taught narrative text by using CIRC) was $49.40(\mathrm{SD}=9.717)$ and the control group (in this case group which is taught using conventional method) was 47.50 (SD = 9.208). It means that the experimental group and the control group were relatively different before the intervention. Moreover, the descriptive 
statistics of post-test for both groups showed that the mean score of experimental group was $62.60(\mathrm{SD}=9.587)$. The increase of the mean score of the experimental group was 13.2 or $26.72 \%$, while the mean score of the control group was 55.64 (SD = 13.587) with an increase of 8.14 or $17.13 \%$. The increase of the mean score of teaching narrative text by using CIRC method is relatively higher than the conventional method group.

From the result above, the mean score of the post-test were different. The post-test mean score of control group is lower than experimental group: $52.92<$ 62.60 , but we cannot conclude that the technique used in experimental group is more effective than the control group because they had relatively different mean score in pre-test. Therefore, analysis of covariance (ANCOVA) was conducted to test the hypothesis. The ANCOVA suggested a statistically significant effect for the pretest $(F(1,48)=71.10, p<.05)$. More importantly, there was a statistically significant effect for the method of instruction $(F(1,48)=13.56, p<.05)$, with a large effect size (explained by the value of eta Squared .23; suggesting $23 \%$ of the variance in reading comprehension was explained by the method of instruction).

Findings of this study are similar with some other previous studies on this topic, particularly the one by Darmayanti (2014), who studied the effect of CIRC method on students' reading comprehension of narrative text. She found that there was significant difference between the students' score who were taught under the CIRC method and non-CIRC method. In addition, Samlan (2010) in a classroom action research using CIRC, showed that CIRC could improve the students' reading comprehension. Durukan (2011) also found the effects of CIRC method on reading and writing for primary school students. Based on the statistical analysis, it was revealed that there was a statistically significant difference between the reading and writing skills of the experimental and control groups in terms of academic achievement and retention.

In most CIRC activities, students follow a sequence of teacher instruction, team practice, team pre-assessments and quizzes so that they do not take the quiz until their teammates have determined that they are ready. Teachers in CIRC method use reading texts and reading groups, as much as in traditional reading programs. However, all students are assigned to teams composed by two pairs from two different reading groups. While the teacher is working with one reading group, the paired students in the other groups are working on a series of engaging activities, including reading to one another, making predictions about how narrative stories will come out, summarizing stories to one another, writing responses to stories, and practicing spelling, decoding, and vocabulary. Students work as a team to master the main idea and other comprehension skills. During language arts periods, students engage in writing drafts, revising and editing one another's work, and finalizing the team books (Slavin, 2011). 
Additionally, students in CIRC strategy can cooperate in a heterogeneous member of group in which the students who have higher ability in reading comprehension can work together with those the students who have low ability. It doesn't mean that students who have low ability depend on the students who have higher ability, but the principle in this strategy is like helping each other in achieving the learning purpose. Slavin (2011) Stated that Cooperative learning refers to instructional methods teachers use to organize students into small groups, in which students work together to help one another learn academic content. Cooperative learning methods are extensively researched, and under certain well-specified conditions they are known to substantially improve student achievement in most subjects and grade levels.

We found that in our study CIRC strategy accommodates almost all students active in the class involved in the activities. This is different with class that was taught by using conventional method, students only used translation and understanding of the text, which make the students, especially lower group students feel afraid and shy to be involved in learning process. The researchers argued that conventional teaching that only used was translation; only translating the text from second language to the first language will make students have difficulties to understand and comprehend the text, because those need grammatical adjustment. The researchers also found that CIRC is a comprehensive reading and writing program for students in the second grades through eight. It includes story-related activities, direct instruction in reading comprehension, and integrated reading and language arts activities. Pairs of students (grouped either by or across ability levels) read to each other, predict how stories will end, summarize stories, write responses, and practice spelling, decoding, and vocabulary. Within cooperative teams of four, students work to understand the main idea of a story and work through the writing process.

It should also be noted that background knowledge and students' vocabulary mastery may become a crucial part in the teaching of reading to make students good at reading comprehension. Because students may comprehend texts better when these ones are culturally familiar or when they relate to well-developed disciplinary knowledge acquired by the students. Teachers need to figure out other teaching strategies that would work for the teaching of comprehension of the students, especially in connecting their background knowledge. Parlindungan (2017) mentioned that providing context of reading might help connecting students' prior knowledge. For example, building connection between what students read at home and school may provide a window to students' current knowledge of the text being read.

Finally, in this study the researchers used CIRC strategy in the teaching narrative text. The researcher wanted to know the effect of this strategy, whether students who were taught narrative text using CIRC would have better results in 
reading comprehension than the students who were taught narrative text using conventional teaching. The result showed that students who are taught narrative text by using CIRC strategy have higher score than those who in which narrative text is taught by using conventional strategy.

\section{Conclusion}

Based on the hypothesis testing, it is clearly known that there was a significant difference in students' reading comprehension between those who were taught narrative text by using CIRC strategy (experimental group) and those who were taught narrative text by using conventional teaching strategy (control group). The gain score from experimental group and control group led to the rejection of the null hypothesis which stated that there is no significant effect on the students' reading comprehension that is taught by using CIRC strategy. It suggests that teaching narrative text by using CIRC strategy is effective to be applied or used in the teaching narrative text mainly in determining the main idea, explicit, implicit meaning and several events of the story.

In accordance with the conclusion above, we provide suggestions for English teachers and future researchers. While teaching reading, the teacher should consider factors affecting reading comprehension, so that teachers can teach reading effectively and select a suitable technique and learning aid that will be used in their teaching. CIRC should be considered as an effective comprehension strategy for teaching narrative text. In teaching reading, the teacher should also cover vocabulary building because the vocabulary mastery is very crucial in the process text comprehension process.

For further researchers, this study only investigated narrative text of students reading comprehension and composition that focus on folktale and fairytale story. Future researcher may examine the effect of CIRC strategy on reading and writing skills in other texts genre. Similar studies may also be conducted with larger population and sample and a better experimental design.

\section{References}

Adams, M. (1990). Beginning to read: Thinking and learning about print. Massachusetts: The Massachusetts Institute of Technology Press.

Ary, D., Jacobs, L.C., \& Razavieh, A. (1979). Introduction to research in Education (2 ${ }^{\text {nd }}$ Edition). DC: Library of Congress Cataloging in Publication Data.

Block, C. C., Gambrell, L. B., \& Pressley, M. (2002). Improving comprehension instruction: Rethinking research, theory, and classroom practice. SF: Jossey-Bass.

Clay, M. (2001). Change over time in children's literacy development. Portsmouth, NH: Heinemann. 
Cowan, N. (2008). What are the differences between long-term, short-term, and working memory? Progress in Brain Research, 169, 323-338. http://doi.org/10.1016/S0079-6123(07)00020-9

Darmayanti, D. (2014). The implementation of cooperative integrated reading and composition (CIRC) method in teaching narrative text to improve students' reading comprehension at the eleventh grade students of MAN 2 Model Makassar. Ethical Lingua, 1(2), 111-123.

Durukan, E. (2011). Effects of Cooperative Integrated Reading and Composition (CIRC) Technique on Reading-Writing Skills. Department of Turkish Education, Faculty of Fatih Education, Black Sea Technical University, Turkey. Educational Research and Reviews Academic Journals 6(1), 102-109.

Kintsch, W. (2013). Revisiting the construction-integration model of text comprehension and its implications for instruction. In D. E. Alvermann, N. J. Unrau, \& R. B. Ruddell (Eds.), Theoretical models and processes of reading (6th ed., pp. 807-839). Newark, DE: International Reading Association.

Kong, A., \& Pearson, D. P. (2003). The road to participation: The construction of a literacy practice in a learning community of linguistically diverse learners. Research in the Teaching of English, 38(1), 85-124.

National Institute of Child Health and Human Development (NICHD). (2000). Report of the national reading panel. Teaching children to read: An evidence-based assessment of the scientific research literature on reading and its implications for reading instruction. (NIH Publication No. 00-4769). Washington, DC: U.S. Government Printing Office.

Paris, S., \& Stahl, S. (2005). Children's reading comprehension and assessment. Mahwah, NJ: Lawrence Elbraum Associates.

Parlindungan, F. (2017). Exploring literacy practices in a second language. TEFLIN Journal, 28(1), 115-132.

Pearson, P.D., \& Fielding, L. (1991). Comprehension instruction. In Barr, R., Kamil, M., Mosenthal, P, \& Pearson, P. D. (Eds.), Handbook of reading research, Volume II, (pp. 815-860). NY: Longman Publishing Group.

Samlan. (2010). Improving reading Comprehension skill of grade XII Students at SMAN 3 Lamongan through Cooperative Integrated Reading and Composition (CIRC), (Unpublished thesis), Islamic University of Malang, Malang

Slavin, R. E. (1988). Technical proposal. Center for research on the education of disadvantage students. Baltimore, MD: The John Hopkins University.

Slavin, R. E. (2011). Co-operative learning: what makes groupwork work?. Johns Hopkins University and University of York.

Snow, C., Burns, M., \& Griffin, P. (1998). Preventing reading difficulties in young children. Wachington, DC: National Academy Press.

Vygotsky, L. S. (1978). Mind in society: The development of higher psychological processes. Cambridge, MA: Harvard University Press.

Wood, D. (1998). How children think and learn (2nd ed.). Malden, MA: Blackwell Publishing. 